\title{
KEARIFAN LOKAL DALAM PEMBELAJARAN BAHASA INGGRIS: SARANA MENINGKATKAN KETERAMPILAN PELAJAR BAHASA INGGRIS DEWASA
}

\author{
Aco Nasir ${ }^{1 *}$, Andriani ${ }^{1}$ \\ IUniversitas Al Asyariah Mandar \\ *Email: aconasir@mail.unasman.ac.id
}

\begin{abstract}
This study aims at investigating the effect of the integrated local wisdom on English Learning at university Students. The research employed a quasi-experimental design. The experimental class was taught by implementing the integrated local wisdom on English Learning and the non-experimental class by conventional strategy. The subject was the 152 second semester students of Non-English Language teaching Department, Al Asyariah Mandar University. The sample was randomly selected to be one of the classes into the experimental group and the other one into the control group. Since the statistical assumptions were not fulfilled in this study therefore, the data were analyzed by utilizing non parametric testing: Mann-Whitney $U$ and Kruskall-Wallis. The mean score of the students' reading comprehension achievement in the end of the study was 79.63 in the experimental group while the mean score of the students' achievement in control group was 56.76 and the p-value was .000, meaning was smaller than level of significance 0.05 ( sig $0.000<0.05$ ). The finding showed that the integrated local wisdom on English Learning statistically impacted students' skill using English as Communication devise in daily life compared to one taught using the Conventional strategy.
\end{abstract}

Keywords: integrate, local wisdom, learning english, mandar

\section{PENDAHULUAN}

Pada dasarnya, Setiap suku tentunya memiliki keunggulan lokal masingmasing. Keunggulan lokal pada suatu suku masyarakat dapat muncul sesuai kondisi geografis, natural resources, human resource, sejarah, dan budaya (Cantrell, W. H., 2000) (Nadlir, 2014; Suherman, 2017; Kahar, Hariyono\& Sumarmi 2017). Sehingga lahirnya beragam kearifan lokal suatu suku masyarakat dapat terkonservasi dari generasi ke genarasi, yang pada akhirnya mampu berperan untuk memperkuat identitas jati diri suku bahkan jati diri suatu bangsa. 
Polewali mandar merupakan satu kabupaten di Provinsi Sulawesi barat yang memiliki beraneka ragam kearifan lokal yang sangat perlu diangkat kepermukaan agar nilai-nilai budaya lokal tersebut tidak mengalami kemerosotan akibat pengaruh budaya luar yang sangat pesat perkembangannya. Keanekaragaman kearifan lokal suku mandar seperti sikap religius, tangggung jawab, rasa malu, kemanusiaan, gotongroyong, disiplin, merupakan bagian dari kearifan lokal yang ada di polewali mandar (Kahar, Hariyono\& Sumarmi 2017). Polewali Mandar memiliki sejumlah kekhasan kearifan budaya lokal. Seperti lopi sandeq, Totammaq, kesenian sayyang pattuduq, Kalindadaq, silulua (gotong royong), Sipakalaqbiq,. Kearifan semacam ini merupakan suatu asset yang sangat bernilai tinggi yang sudah seharusnya oleh generasi muda lestarikan.

Melalui studi ini, peneliti menawarkan sebuah strategi untuk mengangkat Kearifan budaya Lokal masyarakat Mandar ke permukaan agar berbagai kearifan lokal mandar ini tetap eksis dalam tatanan kehidupan sosial. Strategi yang peneliti angkat yaitu berupa pengintegrasian kearifan lokal masyarakat mandar kedalam matakuliah Bahasa Inggris. Strategi ini merupakan langkah konkrit peneliti untuk menanamkan pengetahuan tentang kearifan budaya lokal kepada para pelajar sehingga keterampilan berbahasa yang dimiliki oleh para pelajar mampu diterapkan untuk memperkenalkan kearifan budaya lokal kepada khalayak umum baik ditingkat nasional maupun pada tingkat internasional.

Salah satu kendala dalam mengajarkan bahasa inggris di Universitas AlAsyariah Mandar adalah masih minimnya Bahan ajar sehingga hal ini dapat memicu pengajaran bahasa inggris tidak efektif. Hal inilah yang menjadi dasar peneliti mengangkat topik "Integrasi kearifan lokal masyarakat mandar pada matakuliah bahasa inggris". Hasil penelitian ini akan dikemas menadi sebuah buku ajar yang kemudian diharapkan bisa dijadikan sebagai bahan ajar pokok pada pengajaran matakuliah bahasa inggris di Universitas Al-Asyariah Mandar.

Penelitian ini bertujuan untuk mengetahui pengaruh integrasi kearifan lokal terhadap pembelajaran bahasa Inggris pada mahasiswa dengan mempertimbangkan jawaban atas pertanyaan berikut.

Apakah ada perbedaan Keterampilan pelajar Bahasa Inggris antara siswa yang diajar menerapkan integrasi Kearifan lokal pada Matakuliah bahasaInggris dan siswa yang diajar dengan menggunakan Strategi Konvensional. 


\section{METODE PENELITIAN}

Populasi sasaran penelitian ini adalah 155 mahasiswa semester dua Program Studi Non-Pendidikan Bahasa Inggris Universitas Al Asyariah Mandar. Pemilihan universitas ini didasarkan pada alasan karena strategi yang diterapkan menekankan untuk mengaktifkan mahasiswa dalam berdiskusi. Strategi ini lebih sesuai dengan siswa yang memiliki latar belakang pengetahuan yang cukup sehingga menjadi salah satu alasan untuk memilih mahasiswa daripada siswa di sekolah. Penelitian ini dilakukan di Universitas Al Asyariah Mandar dengan Subjek penelitian adalah 152 mahasiswa semester dua Jurusan Non-Bahasa Inggris Universitas Al Asyariah Mandar. Sampel dipilih secara acak untuk menjadi salah satu kelas ke dalam kelompok eksperimen dan satu lagi ke dalam kelompok kontrol. Kemampuan siswa diakui homogen dan memungkinkan saya memutuskan mereka untuk dipilih. Hal tersebut berdasarkan sistem pengambilan mata kuliah bahwa mahasiswa yang tidak lulus pada semester pertama tidak diperkenankan mengambil mata kuliah Bahasa Inggreis II pada semester kedua.

Selain itu, seluruh mahasiswa telah mengikuti mata kuliah Bahasa Inggris I pada semester pertama dan mahasiswa yang tidak lulus pada mata kuliah Bahasa Inggris I tidak diperkenankan untuk mengambil mata kuliah Bahasa Inggris II. Hal ini menunjukkan bahwa populasi yang dapat diakses dari penelitian ini adalah 155 mahasiswa baru yang berusia antara 18-21 tahun yang memantau perkembangan keterampilan Bahasa Inggris.

Terdapat dua belas Prodi yang terdiri dari 155 mahasiswa semester dua tahun ajaran 2019-20200. Kemudian dipilih dua kelas secara acak sebagai sampel dari populasi yang berjumlah 50 mahasiswa. Pemilihan kelompok didasarkan pada pemilihan secara acak menggunakan lotere koin dan oleh karena itu lempar koin dilakukan. Pemilihan acak dilakukan dengan melempar koin sebanyak 15 kali dan menentukan ekor atau kepalanya. Kemudian diputuskan menjadi kelompok eksperimen dan kelompok kontrol. Ini didasarkan pada kepala koin dan penampilan ekor koin. Jika kepala koin muncul lebih dari pada ekornya maka itu akan dikategorikan sebagai kelompok eksperimen dan sebaliknya. Selain itu, ini juga pada dasarnya untuk memastikan bahwa semua aspek dari kedua kelompok (kelompok eksperimen dan kontrol) adalah sama atau homogen.

Penelitian ini mengkombinasikan antara metode kuantitatif dankualitatif untuk digunakan secara bersama-sama dalam suatu kegiatan penelitian sehingga diperoleh data yang lebih komprehensif, valid, reliable dan objektif itu sebapnya metode itu yang cocok untuk diguanakan dalam penelitian ini adalah Mix-method. Desain penelitian ini menggunakan Sequential Explanatory. Model penelitian Sequential Explanatory Design dicirikan dengan melakukan pengumpulan data dan analisis data kuantitatif pada tahap pertama dan diikuti dengan pengumpulan dan analisis datakualitatif pada tahap kedua, guna memperkuat hasil penelitian 
kuantitatif yang dilakukan padatahap pertama untuk kemudian diambil kesimpulan dari analisis data tersebut (Sugiono. 2010).

Berdasarkan penjelasan diatas, maka peneliti merumuskan bagan alir penelitian yang dapat dilihat pada gambar 1 berikut:

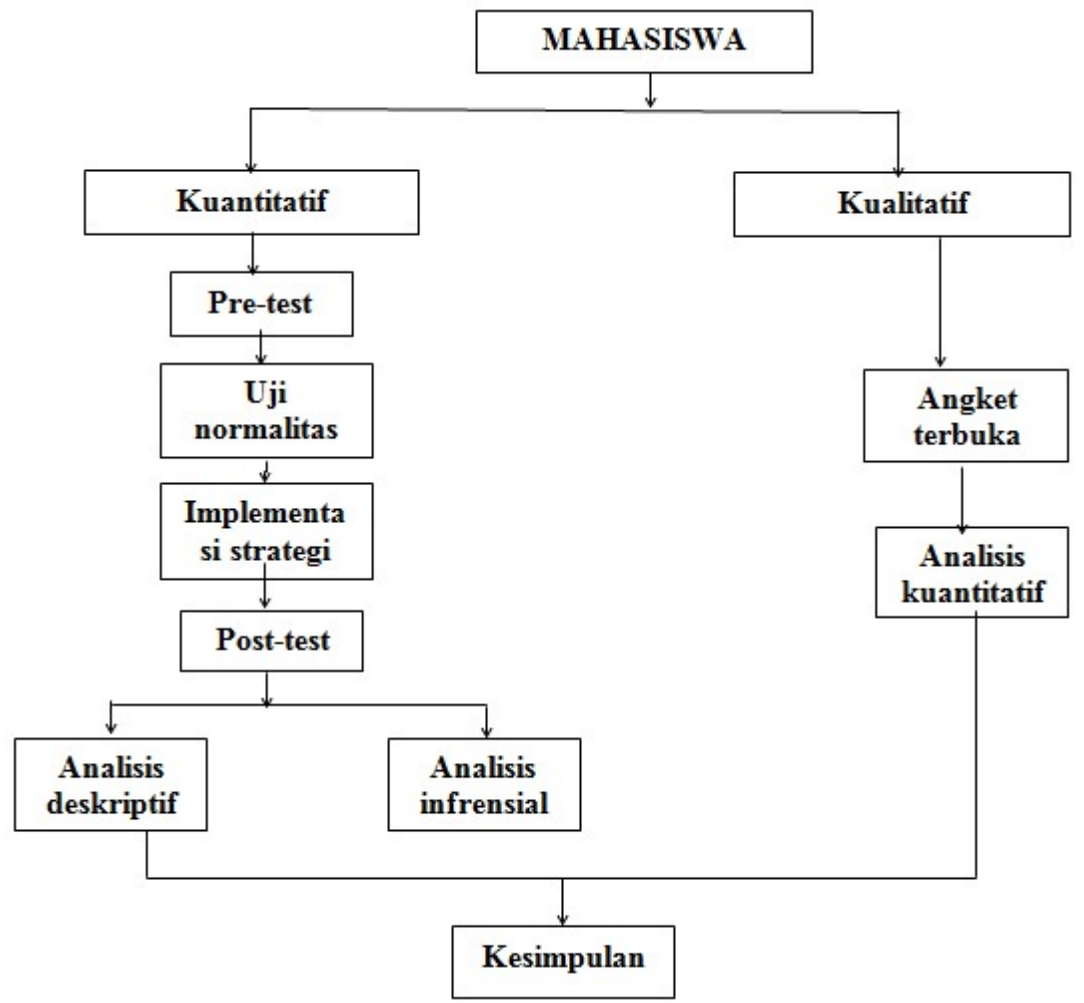

Gambar 1. Bagan alir penelitian

Instrumen penelitian yang digunakan untuk mengumpulkan data kuantitatif adalah tes uraian yang terdiri dari pretes dan postes. Pretes merupakan materi prasyarat "deskriptif teks" yaitu pendekripsian penggambaran secara detai tentang topik tertentu dalam hal ini objek kajian adalah kearifan lokal masyarakat mandar.Sedangkan postes merupakan tes uraian kinerja dimana setiap mahasiswa diberikan tugas untuk memperkenalkan kearifan budaya lokal masyarakat mandar dengan cara menjelaskan apa saja kearifan budaya lokal yang telah mereka ketahui. Pretes diberikan sebelum menerapkan strategi pembelajaran integrasi kearifan lokal pada pelajaran bahasa inggris dan postes 
diberikan setelah menerapkan strategi pembelajaran.Penelitian ini dilaksanakan selama 8 kali pertemuan.

\section{HASIL DAN PEMBAHASAN}

Bagian ini memaparkan temuan penelitian dan verifikasi atas hipotesis penelitian. Seluruh data dalam bagian ini disediakan untuk menentukan apakah penerapan intergrasi Keariafan Lokal dalam Pembelajaran Bahasa Inggris efektif terhadap pencapaian keterampilan berbahasa Inggris Pelajar atau tidak, yang dihitung melalui prosedur statistik dalam pengujian hipotesis. Dengan kata lain, data dianalisis untuk memberikan penjelasan rinci tentang pengaruh Pengintegrasian Kearifan lokal pada Matakuliah Bahasa Inggris. Studi ini menerapkan desain kuasi-eksperimental itu sebapnya data studi ini merupakan data kuantitatif selain juga didukung data berdasarkan hasil aktifitas para pelajar serta keterlaksaan studi selama proses pembelajaran sehingga studi ini juga memperoleh data kualitatif.

\section{Analisis data dari Instrumen Tes keterampilan berkomunikasi bahasa Inggris \\ Hasil Post-Test}

Berdasarkan hasil post-test pada kelompok eksperimen dan kelompok kontrol menunjukkan bahwa skor rata-rata untuk kelompok eksperimen adalah 79,63 sedangkan skor rata-rata untuk kelompok kontrol adalah 56,76. Perbedaan nilai rata-rata antara kelompok eksperimen dan kelompok kontrol diilustrasikan pada Tabel 1 berikut:

Tabel 1. Hasil analisis post test

Sumber: Hasil Olah Data 2020

\begin{tabular}{|l|l|l|}
\hline & Kelompok Eksperimen & Kelompok Kontrol \\
\hline Min & 70 & 50 \\
\hline Max & 95 & 65 \\
\hline Mean & 79.6324 & 65.7646 \\
\hline Std. Deviation & 8.00408 & 11.72813 \\
\hline N & 34 & 34 \\
\hline
\end{tabular}

Tabel diatas menunjukkan bahwa ada perbedaan skor rata-rata antara kelompok eksperimen dan kelompok kontrol. Hal ini menunjukkan nilai rata-rata prestasi belajar siswa pada eksperimen adalah 79,63 sedangkan nilai rata-rata siswa pada kelompok kontrol adalah 56,76. Skor minimum dan maksimum diungkapkan pada kedua kelompok. Hal ini menunjukkan nilai minimum pada kelompok eksperimen adalah 70 dan nilai maksimum 95 dengan jarak 25 dan standar deviasi 8,00408. Sedangkan skor minimal pada kelompok kontrol adalah 50 dan skor maksimal 65 dengan rentang 50 dan standar deviasi 11,72813. Standar deviasi pada kedua 
kelompok juga berbeda.Kelompok kontrol perlakuan memiliki nilai standar deviasi yang lebih besar.Artinya, skor siswa lebih dihargai pada kelompok kontrol.Rentang dan persebaran skor prestasi setelah perlakuan pada kelompok kontrol lebih luas.Karena perlakuan pada kelompok eksperimen memiliki standar deviasi yang lebih rendah, kami melihat bahwa siswa memiliki reaksi yang lebih konsisten terhadap perlakuan kelompok eksperimen.

Data ini juga dicontohkan secara visual pada gambar 2 berikut:

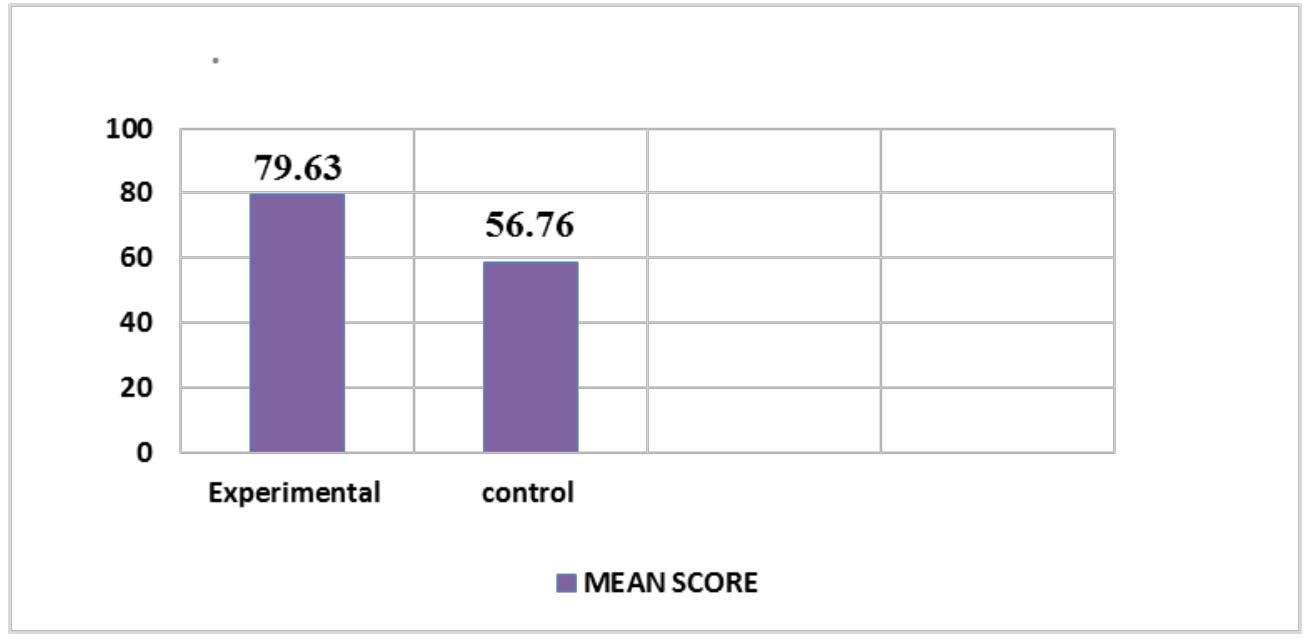

Gambar 2. Rata-rata Post-Test Kelompok Eksperimen dan Kelompok Kontrol

Diagram diatas menunjukkan bahwa nilai rata-rata kelompok eksperimen berbeda dengan nilai rata-rata kelompok kontrol. Hal ini menunjukkan bahwa nilai ratarata kelompok eksperimen adalah 79,63 pada akhir penelitian, sedangkan pada kelompok kontrol adalah 56,76. Artinya, prestasi belajar pemahaman bacaan siswa setelah perlakuan pada kelompok eksperimen lebih besar daripada kelompok kontrol.Oleh karena itu, saya menyimpulkan berdasarkan temuan ini bahwa intergrasi Kearifan Lokal pada Matakuliah Bahasa Inggris berpengaruh secara positif terhadap prestasi belajar para pelajar.

\section{Analisis data dari Instrumen Non-Tes}

\section{Hasil Observasi Aktifitas Pelajar}

Observasi aktivitas siswa dilakukan setiap kali pertemuan yaitu sebanyak 6 kali pertemuan. Adapun tabel kategori keaktifan aktivitas siswa dapat dilihat pada tabel 2 berikut: 
Tabel 2. Kategori Keaktifan Aktivitas Siswa Sumber : Suharsimi, A. (2006).

\begin{tabular}{|l|l|}
\hline Persentase & Kategori \\
\hline $90 \%<\mathrm{x} \leq 100 \%$ & Sangat aktif \\
\hline $75 \%<\mathrm{x} \leq 90 \%$ & Aktif \\
\hline $60 \%<\mathrm{x} \leq 75 \%$ & Kurang aktif \\
\hline $40 \%<\mathrm{x} \leq 60 \%$ & Tidak aktif \\
\hline $0 \%<\mathrm{x} \leq 40 \%$ & Sangat tidak aktif \\
\hline
\end{tabular}

Data rata-rata hasil observasi aktivitas siswa selama proses Pembelajaran bahasa inggris dapat dilihat pada tabel 3 berikut.

Tabel 3. Rata-rata hasil observasi aktivitas siswa Sumber: Hasil Olah Data 2020

\begin{tabular}{|c|c|c|}
\hline Pertemuan & Persentase (\%) & Kategori \\
\hline 1 & 65,32 & Kurang Aktif \\
\hline 2 & 70 & Kurang Aktif \\
\hline 3 & 80,47 & Aktif \\
\hline 4 & 85 & Aktif \\
\hline 5 & 95 & Sangat Aktif \\
\hline 6 & 90 & Sangat Aktif \\
\hline
\end{tabular}

Paparan tabel diatas menunjukkan reaksi sikap para pelajar selama proses pembelajaran, data tersebut menunjukkan adanya reaksi yang kurang direspon oleh para pelajar pada pertemuan awal. Hal ini disebapkan oleh sejumlah faktor diataranya karena susahnya menhadapi suasana kehidupan baru akibat pandemi covid-19.Sejumlah aktifitas pembelajaran berubah drastis. Proses pembelajaran dipaksa untuk bisa dilakukan secara daring kalaupun ada pertemuan secara tatapmuka hanya sebagian kecil saja. Sementara belum semua para pelajar siap menghadapi suasana baru.Sejumlah alasan para pelajarpun beragam ada yang kesuilitan memperoleh jaringan internet, kouta dataterbatas, dan sebagian ada yang mudik. Inilah yang merupakan salah satu penghambat ketidak siapan pelajar melaksanakan pembelajaran sehingga berefek pada kekuranng aktifan para pelajar pada pertemuan awal.

Demikian juga pada pertemuan kedua masih tampak kurang aktif namun demikian sudah mulai muncul reaksi positif para pelajar walaupun masih dalam kategori kurang aktif.Peneliti mencoba memperbaiki strategi sehingga membuat para pelajar antusias belajar semua yang merupakan kekurangan pada pertemuan awal hingga kedua dievaluasi.Hasil dari evaluasi Nampak ada perubahan positif 
yang menunjukkan para pelajar mulai Nampak aktif hingga pertemuan ke empat bahakan pada pertemuan akhir menunjukkan reaksi yang sangat aktif dalam menerima pelajaran bahasa inggris yang dintegrasikan pada kearifan lokal.

\section{SIMPULAN}

Studi ini didasarkan pada berbagai sumber tentang Pengintegrasian Kearifan Lokal terhadap matakuliah sebagai upaya melestarikan berbagai kearifan lokal yang saat ini terancam tergeser akibat pengaruh budaya asing yang tidak terelakkan. Upaya mempertahankan serta melesatarikan sejumlah kearifan lokal suku mandar Seperti Seni Parrawana, Pamaccaq, Kalindaqdaq, pappatamaq, Tenun, Sayyang Pattuduq dan lainnya merupakan tindakan yang sudah semestinya dilakukann oleh para generasi khusunya generasi masyarakat Suku Mandar karena jika bukan masyarakat lokal dalamhal ini masyarakat suku mandar yang yang tidak atau enggang melestariakanbn budaya lokal maka tunggulah kepunahan sejumlah kearifan lokal tersebut sedikit demi sedikit. Mengintegrasikan kearifan lokal pada matakuliah merupakan suatu tindakan konkrite untuk melestarikan budaya lokal. Inti utama dari studi ini mengungkap pengaruh integrasi kearifan lokal terhadap pembelajaran bahasa Inggris pada mahasiswa. hasil penelitian menunjukkan bahwa kearifan lokal terintegrasi dalam Pembelajaran Bahasa Inggris secara statistik berdampak positif pada keterampilan siswa dalam menggunakan Bahasa Inggris sebagai Perangkat Komunikasi dalam kehidupan sehari-hari dibandingkan dengan yang diajarkan dengan menggunakan strategi Konvensional.

\section{SARAN}

Berdasarkan temuan sekaligus pembahasan di atas, maka peneliti memberikan saran sebagai berikut:

1. Pengajar yang tertarik untuk melaksanakan pengintegrasian Kearifan lokal terhadap matakuliah harus mempertimbangkan langkah-langkah berikut: (a) Pengajar harus membuat rencana yang baik sebelum mengajar, (b) Pengajar harus memberi petunjuk dan penjelasan yang jelas tentang kegiatan yang akan dilakukan siswa di kelas, (c) Pengajar harus memotivasi dan mendorong siswanya untuk aktif selama proses belajar mengajar, (d) Pengajar harus berkeliling dan memantau kegiatan siswa dan beri mereka bantuan saat mereka mendapat kesulitan dan (e) Pengajar hendaknya membimbing dan memfasilitasi siswa selama kegiatan belajar-mengajar.

2. Peneliti lain yang tertarik untuk membuat rancangan pembelajaran berbasis kearifan lokal disarankan untuk dikembangkan untuk mengajarkan keterampilan lain seperti berbicara, mendengarkan, atau menulis. Bahkan, memperhatikan perkembangan psikologis siswa. 


\section{DAFTAR PUSTAKA}

Kahar, Hariyono\& Sumarmi 2017. Kearifan Budaya Lokal Polewali Mandar Sebagai Sumber Pembelajaran Ipspublished on journal UM Malang

Kahar, Hariyono\& Sumarmi 2017. Kearifan Budaya Lokal Polewali Mandar Sebagai Sumber Pembelajaran Ipspublished on journal UM Malang

Nadlir, 2014.Urgensi Pembelajaran Berbasis Kearifan Lokal journal Pendidikan Agama Islam Vol.02 nomor 2 november 2014

Sugiono. 2010. Metode Penelitian Kuantitatif, Kualitatif dan R\&D. Bandung: Alfabeta.

Sugiono. 2012. Metode Penelitian Kombinasi (Mixed Methods). Bandung: Alfabeta Suharsimi, A. (2006). Prosedur penelitian suatu pendekatan praktik. Jakarta: Rineka Cipta

Suherman, 2017. Pengembangan Bahan Ajar IPS Berbasis Kearifan Lokal AIQ NYERENG Tunjung Tilah Empak Bau) Pada Tema Pengenalan Alam Lingkungan Sekitar. Thesis Pascasarjana Universitas Islam Negeri Maulana Malik Ibrahim Malang 